\title{
The Readiness Level of Teachers in Science, Technology, Engineering and Mathematics Education ${ }^{i}$
}

\author{
Sevim Asiroglu, ${ }^{1, *}$, Sevda Koc Akran ${ }^{2}$ \\ ${ }^{1}$ Department of Educational Science, Faculty of Education, Maltepe University, İstanbul, Turkey \\ ${ }^{2}$ Department of Educational Science, Faculty of Education, Siirt University, Siirt, Turkey
}

Copyright $\mathrm{C} 2018$ by authors, all rights reserved. Authors agree that this article remains permanently open access under the terms of the Creative Commons Attribution License 4.0 International License

\begin{abstract}
The aim of this research is to determine the viewpoints and readiness of class, mathematics and science teachers on STEM (Science, Technology, Engineering and Mathematics) Education. The other aims are to determine different between branches and seniority in the readiness of teachers on STEM Education. The review method was used in the study the sampling of the study consisted of 371 teachers, who were selected randomly from Siirt and Batman. A questionnaire was developed by the authors of the study to determine the readiness of the teachers on STEM Education. Frequencies, arithmetic averages and the Kruskal Wallis $H$ was used in this research. The teachers who participated in the study believe that they are inadequate about implementing teaching designs that are inventive, use scientific methods, develop creative STEM products, and aim to raise students who critically examine these products. In addition, they do not see themselves adequately in terms of process evaluation, assisted education in information technology, development of engineering applications suitable for the student level, analysis according to Bloom taxonomy and activities related to higher skill levels. Among the issues that teachers see themselves as middle level and above it are project-based, probabilistic learning and structuring of knowledge.
\end{abstract}

Keywords Science Education, Mathematics Education, Teknology Education, Engineering, Teacher Trainer

\section{Introduction}

In order to raise individuals who have specialization in certain fields, disciplines such as science, mathematics, engineering and technology (STEM) have been dealt with for long years. As of the $21^{\text {st }}$ Century, the need arose to handle these fields in an integrated manner rather than dealing with them in a separate way due to the requirements of Information and Technology Age [1]. The term STEM was formed by using the initials of Science, Technology, Engineering, and Mathematics. STEM Education may be defined as an interdisciplinary learning approach that involves the integration of these four disciplines [2] Constructive education approach includes several areas like project-based learning and problem-based learning. It is aimed that the $21^{\text {st }}$ Century skills like creativity, critical thinking, cooperative working and problem solving are acquired by the labor force of the future, i.e. young people when they are at formal education years. Individuals are expected to use their creativity and their theoretical knowledge, and convert their efforts into a product or an innovation for the purpose of solving real life problems [3]. In this way, permanent and meaningful learning is ensured [4].

There is a need for specialist students in the field of STEM to solve the $21^{\text {st }}$ Century problems. Developed countries have performed several interventions to be the leaders in scientific field, to ensure economic growth and to raise citizens that have entrepreneur spirit in economic and technological fields [5]. For this purpose, the United States of America defined a set of standards for national science education, and opened STEM Schools in many states. The European Union issued a report intended for inquiry based science education, and encouraged teachers by creating communication networks for them in the field of projects related with this field In Turkey, the desired success level was not achieved in several tests 8 [5]; and as a result of this situation, new ways have been sought by authorities in this field. Ministry of National Education, Innovation and Education Technologies General Directorate issued a report, and made several recommendations for initiating the STEM Education. Most of the teachers, who joined the Scientix Project of the Innovation and Education Technologies, General Directorate, think that STEM Education must be initiated at once [6].

In Turkey, several purposes were mentioned in the 2015-2019 Strategic Plan about strengthening STEM Education [6]. The Ministry of National Education has 
included the STEM Education partly by including engineering practices and design skills in secondary school science program. Studies conducted in Turkey show that STEM education has positive effects in certain elements like the attitudes, motivations, interests, and scientific process skills of students $[7,8,9]$.

Firstly, teachers should be trained for STEM education, which is becoming widespread both in our country and in many other countries. For this purpose, qualified programs for in-service training of teachers must be designed. The first step in designing such a program is setting goals. One of many inputs of STEM-related in-service training programs to achieve the preset targets is the availability of teachers to treat as the learning groups; because, as Sonmez [10] pointed out, it is necessary to start education from the readiness level of the learning group.

Corlu, Capraro and Capraro [11] claimed that teachers' having mere specialty knowledge was not adequate in raising qualified labor power that was needed. It was reported in many previous studies that many previous studies trainings should be increased for teachers about STEM Education [12, 13, 14].

There were various problems about the application of the STEM Education [15]. Some additional training must be provided for teachers in the designing and planning process of a STEM Education, because some teachers might resist to innovations, and prevent the accurate functioning of such an education by claiming that they do not have adequate background knowledge on this topic. In order to avoid such problems with teachers, it is necessary that the designers of such a program are aware of the cognitive, dynamic and affective characteristics of participant teachers.

There are no classes or subjects for STEM education in the in-service training received by teacher candidates at university education in the national education structure in Turkey [16]. The relevant topics in such training programs may be cognitive learning approaches, alternative measurement and evaluation, and educational technologies. In addition, teachers must have the skill of being able to use the four disciplines, which are Science, Technology, Engineering, and Mathematics, for a successful STEM Education. So, it is highly possible that teachers might face several problems in applying the STEM Education. For this reason, the analyses of the needs must be made very well for designing a STEM Education for teachers. Based on these facts, the aim of the present study was to determine the viewpoints and readiness of teachers working at primary and secondary schools on STEM Education. In this context, answers were sought to the following questions:

1. How is the distribution of teachers in STEM Education according to their readiness levels?

2. Are there differences between the readinesses of teachers in terms of readiness for STEM Education according to their branches?
3. Are there differences between the readiness of teachers in terms of readiness for STEM Education according to their seniority?

\section{Materials and Methods}

The Review Method was used in the study since the aim was to determine and define an existing situation [17]. In this context, the existing readiness levels of teachers on STEM Education were determined and defined.

In 2016-2017 Academic Year, there were 1212 teachers working in Siirt and 2359 teachers in Batman city center. The study group consisted of 353 teachers chosen to represent Siirt and Batman. The distribution of the sample is shown in Table 1.

Table 1. Distribution of the sample

\begin{tabular}{cc}
\hline Brach & Frekans \\
\hline Elementary School teachers & 86 \\
Mathematics teachers & 122 \\
Science teachers & 145 \\
\hline Total & 353
\end{tabular}

There are certain data collection tools evaluating various affective and cognitive characteristics of teachers who do not have STEM education; and most of the tools are directed to teacher candidates. Some of them are as follows:

- The scale that measures the levels of mental readiness for STEM education which was developed by Corlu, Capraro and Capraro (11];

- The scale that aims to determine the attitudes of teacher candidates who are trained in STEM fields which was developed by Buyruk and Korkmaz [18];

- The attitude scale for STEM education of teacher candidates which was developed by Derin, Aydın and Kirkıc [19];

- An open-ended questionnaire form that aims to measure the perceptions of teacher candidates developed by Tutak, Akaygun and Tez sezan [20];

- STEM Semantic Awareness Scale which was developed by Knezek and Christensen and which was adapted into Turkish by Kızllay [21];

- The Integrated STEM Instruction \& Orientation Scale which was developed by Lin and Williams and which was adapted into Turkish language by Haciomeroglu and Bulut [22];

- STEM Awareness Scale for secondary school teachers which was developed by Cevik [23];

- The Qualitative Data Collection Tools developed by Wang, Moore, Roehrig \& Park, [4] to determine the beliefs and perceptions of science and engineering teachers in STEM.

Among all these studies, there were no studies that measured the cognitive readiness of the teachers who are 
in the Turkish national education system for STEM education. For this reason, after the review of the literature was made by the researchers, the achievements that could be a precondition for STEM teacher education were written as a list. While the questionnaire was developed, literature was primarily made use of. According to the literature review, the list of acquisitions for STEM in-service training of teachers was made by the researchers taking into account all kinds of knowledge and skills that teachers had the opportunity to learn and experience. Then, these acquisitions were turned into questionnaire items. A group of teachers who had similar characteristics to the study group who were selected as the study was presented to examine the list in terms of understandability and to an expert for score validity. In line with the opinions and criticisms received, the "STEM Education Readiness Questionnaire for Teachers" was finalized.

The first part of the questionnaire consisted of personal information, and the second part consisted of 32 items, which were rated with 5-Point Likert Scale as; "Not enough (1)", "Not enough (2)", "Moderate enough (3)", "Adequate (4)", "Completely sufficient (5)".

The "STEM Education Readiness of Teachers" Questionnaire was applied between March and April in 2017. The data were recorded in the SPSS.16 Program.

\section{Analyzing of Data}

The Shapiro-Wilk test was used for the normality analysis of the items which were included in the questionnaire; and according to this test, it was determined that the values of the items did not show a normal distribution. The normality values are given in table 2.

After the normality test, it was decided to analyze the data to calculate the differences between the mean of the branch and seniority groups with Kruskal Wallis H-Test and Mann Whitney U-Test. Frequency and arithmetic averages were also calculated. In the present study, since the items were handled independently from each other, no analysis was performed on the reliability of the scores that were obtained (i.e. the Cronbach Alpha internal consistency coefficient). The significance level was accepted to be .05 .

The scoring criteria for the average values of the questionnaire items were as follows; scores between 1-1.49, "Not at all sufficient"; scores between 1.50-2.49, "Not enough"; scores between 2.50-3.49 "Moderate enough"; scores between 3,50-4,49, "sufficient"; 4,50-5 "completely enough"
Table 2. The normality analysis of the items

\begin{tabular}{|c|c|c|c|}
\hline Items & Statistic & $\mathrm{df}$ & $\mathrm{p}$ \\
\hline I 1 & 877 & 371 & ,000 \\
\hline I 2 & ,883 & 371 & ,000 \\
\hline I 3 & 865 & 371 &, 000 \\
\hline I 4 & 834 & 371 & ,000 \\
\hline I 5 & ,722 & 371 & ,000 \\
\hline I 6 & 870 & 371 & ,000 \\
\hline I 7 & 830 & 371 &, 000 \\
\hline I 8 & 860 & 371 & ,000 \\
\hline I 9 & 885 & 371 & ,000 \\
\hline I 10 & ,838 & 371 & ,000 \\
\hline I 11 & 864 & 371 &, 000 \\
\hline I 12 & 829 & 371 &, 000 \\
\hline I 3 &, 785 & 371 & 000 \\
\hline I 14 &, 825 & 371 & ,000 \\
\hline I 15 &, 859 & 371 &, 000 \\
\hline I 16 & 831 & 371 & ,000 \\
\hline I 23 & ,882 & 371 & ,000 \\
\hline I 24 & ,830 & 371 & ,000 \\
\hline I 25 & ,782 & 371 & ,000 \\
\hline I 26 &, 753 & 371 & ,000 \\
\hline I 27 & ,806 & 371 & ,000 \\
\hline I 28 & 874 & 371 &, 000 \\
\hline I 29 & ,730 & 371 & ,000 \\
\hline I 30 & 813 & 371 & ,000 \\
\hline I 31 & 884 & 371 & ,000 \\
\hline I 17 & 860 & 371 &, 000 \\
\hline I 18 & ,892 & 371 &, 000 \\
\hline I 19 &, 853 & 371 & ,000 \\
\hline I 20 &, 858 & 371 &, 000 \\
\hline I 21 & ,767 & 371 & ,000 \\
\hline I 22 & ,802 & 371 & ,000, \\
\hline I 32 &, 825 & 371 & ,000 \\
\hline
\end{tabular}




\section{Findings}

\section{The Findings on the Readiness of the Teachers in STEM Education and Interpretation}

Table 3. The distribution of the findings on the readiness of the teachers in STEM Education

\begin{tabular}{|c|c|c|c|c|c|c|}
\hline Item & 1 & 2 & 3 & 4 & 5 & $\overline{\mathrm{x}}$ \\
\hline 1 & 19 & 82 & 73 & 161 & 36 & 3,30 \\
\hline 2 & 53 & 83 & 52 & 143 & 40 & 3,09 \\
\hline 3 & 18 & 77 & 66 & 172 & 38 & 3,36 \\
\hline 4 & 56 & 196 & 65 & 37 & 17 & 2,36 \\
\hline 5 & 9 & 5 & 26 & 220 & 111 & 4,12 \\
\hline 6 & 8 & 80 & 90 & 164 & 29 & 3,33 \\
\hline 7 & 12 & 56 & 64 & 202 & 37 & 3,52 \\
\hline 8 & 24 & 158 & 70 & 107 & 12 & 2,79 \\
\hline 9 & 32 & 156 & 105 & 62 & 16 & 2,20 \\
\hline 10 & 85 & 195 & 78 & 12 & 1 & 2,16 \\
\hline 11 & 23 & 141 & 72 & 123 & 12 & 2,05 \\
\hline 12 & 50 & 208 & 81 & 26 & 6 & 2,89 \\
\hline 13 & 167 & 84 & 38 & 51 & 31 & 2,27 \\
\hline 14 & 65 & 213 & 78 & 14 & 1 & 2,19 \\
\hline 15 & 72 & 176 & 100 & 23 & 0 & 2,11 \\
\hline 16 & 10 & 46 & 46 & 71 & 40 & 2,19 \\
\hline 17 & 23 & 160 & 73 & 103 & 12 & 2,58 \\
\hline 18 & 32 & 156 & 105 & 62 & 16 & 2,78 \\
\hline 19 & 20 & 141 & 66 & 132 & 12 & 2,79 \\
\hline 20 & 29 & 177 & 75 & 75 & 15 & 2,93 \\
\hline 21 & 144 & 141 & 29 & 39 & 18 & 2,64 \\
\hline 22 & 61 & 22,8 & 67 & 14 & 1 & 2,07 \\
\hline 23 & 17 & 116 & 69 & 134 & 35 & 2,09 \\
\hline 24 & 18 & 167 & 62 & 117 & 7 & 3,14 \\
\hline 25 & 75 & 226 & 49 & 15 & 6 & 2,80 \\
\hline 26 & 71 & 239 & 44 & 11 & 6 & 2,05 \\
\hline 27 & 120 & 191 & 54 & 4 & 2 & 2,03 \\
\hline 28 & 30 & 148 & 78 & 104 & 11 & 1,85 \\
\hline 29 & 2 & 7 & 56 & 260 & 46 & 2,77 \\
\hline 30 & 89 & 212 & 59 & 10 & 1 & 3,91 \\
\hline 31 & 34 & 117 & 51 & 128 & 41 & 1,98 \\
\hline 32 & 72 & 194 & 76 & 15 & 14 & 3,08 \\
\hline
\end{tabular}

As seen in table 3, the acquisitions in which the teachers considered themselves as "sufficient" are as follows:

- $\quad$ Being able to guide students through the activities in lessons to solve their real-life problems with a disciplinary point of view (Item 5);

- $\quad$ Being able to teach students to develop skills such as entrepreneurship and productive skills (Item 7);

- $\quad$ Being able to guide students about how to use the knowledge they gain in science, mathematics, technology and engineering fields in different subjects (Item 30).

The acquisitions in which the teachers find themselves moderately sufficient are;

- $\quad$ Being able to apply class activities for obtaining a product by integrating the information received in the fields of Science, Technology, Engineering and Mathematics (Item 1);

- Being able to apply class activities for obtaining a product by integrating the information received in the fields of Science and Mathematics together(Item 2);

- Being able to apply class activities for obtaining a product by integrating the information received in the fields of Science and Technology (Item 3);

- Being able to guide students to convert scientific knowledge into a product or into practical knowledge (Item 6);

- Being able to apply class activities including the acquisition of a product by integrating the knowledge in the fields of Mathematics and Technology (Item 4);

- Being able to raise investigating and researching individuals (Item 8);

- $\quad$ Preparing a technology-based plan (Item 12);

- Being able to combine experiments/activities in science or mathematics laboratory with engineering design processes (Item 17);

- Being able to teach intended for problem-based learning approach (Item 18);

- Being able to teach intended for performance-based learning approach (Item 19);

- Being able to make teaching intended for project-based learning approach (Item 20);

- Being able to use the 5E Learning Model in planning units and activities (Item 21);

- Being able to use alternative measurement and evaluation techniques (Item 24);

- Being able to guide students to produce research questions like scientists (Item 25);

- Being able to guide students to associate old and new knowledge in science, mathematics, technology and engineering (Item 29);

- Being able to do include activities that will arouse the curiosity in students at every stage of classes while performing activities related to science, mathematics, technology and engineering (Item 32).

The acquisitions teachers do not find themselves sufficient are as follows:

- Being able to develop the skills of product development, invention and innovation by guiding students (Item 9);

- Being able to develop the measurement tools that measure the mental processes of students in 
activities such as investigation, research and invention (Item 10);

- $\quad$ Being able to make use of computer technologies such as interactive boards and tablet computers in classes (Item 11);

- $\quad$ Being able to use engineering applications in line with the levels of students (Item 13);

- Being able to use scientific researches and technological inventions in classes (Item 14);

- $\quad$ Being able to integrate the knowledge gained in digital teaching technologies with the aim of the courses (Item 15);

- $\quad$ Being able to associate instructional design (i.e. plan) with everyday life (Item 16);

- Being able to integrate the 4 disciplines (i.e. Science, Mathematics, Technology, Engineering) when planning units and activities (Item 22);

- $\quad$ Being able to use process and result evaluation together (Item 23);

- $\quad$ Being able to guide students to solve problems through reasoning like scientists (Item 26);
- I contribute to the development of creativity of individuals in the field of science and engineering by employing basic knowledge and skills of them (Item 27);

- $\quad$ Being able to include the activities that will ensure that students approach to knowledge acquired in science, mathematics, technology and engineering in a critical manner (Item 28);

- Being able to include activities that will enable students to analyze, synthesize and evaluate information instead of memorizing (Item 31).

The issues in items $1,2,3,4,6,7,8,12,17,18,19,20$, $21,24,25,29,31$ and 32 relate to the principles of the constructivist approach, which has been applied since 2004 in Turkish national education programs. The reason why teachers feel sufficient in these items may be due to the skills they have acquired when using programs. The other items are related to the subjects that the teachers had not been trained before and did not use. 
The Findings on the Differences in Readiness of Teachers on STEM Education according to Branches

Table 4. The Kruskal Wallis $\mathrm{H}$ results on the readiness of teachers on STEM education according to branch variable

\begin{tabular}{|c|c|c|c|c|c|c|}
\hline Items & Branch & Sum of squares & df & $\chi^{2}$ & $\mathrm{p}$ & Difference \\
\hline \multirow{3}{*}{1} & EST (1) & 151.8 & \multirow{3}{*}{2} & \multirow{3}{*}{13.4} & \multirow{3}{*}{0.0} & \multirow{3}{*}{$\begin{array}{l}1-2 \\
2-3\end{array}$} \\
\hline & MT (2) & 200.3 & & & & \\
\hline & ST (3) & 172.2 & & & & \\
\hline \multirow{3}{*}{6} & EST (1) & 158.0 & \multirow{3}{*}{2} & \multirow{3}{*}{9.90} & \multirow{3}{*}{0.0} & \multirow{3}{*}{$\begin{array}{l}1-2 \\
2-3\end{array}$} \\
\hline & MT (2) & 198.0 & & & & \\
\hline & ST (3) & 170.5 & & & & \\
\hline \multirow{3}{*}{7} & EST (1) & 150.4 & \multirow{3}{*}{2} & \multirow{3}{*}{12,5} & \multirow{3}{*}{0.00} & \multirow{3}{*}{$\begin{array}{l}1-2 \\
1-3\end{array}$} \\
\hline & MT (2) & 196.7 & & & & \\
\hline & ST (3) & 176.1 & & & & \\
\hline \multirow{4}{*}{8} & EST (1) & 205.6 & \multirow{3}{*}{2} & \multirow{3}{*}{17.5} & \multirow{3}{*}{0.0} & \multirow{3}{*}{$\begin{array}{l}1-3 \\
2-3\end{array}$} \\
\hline & MT (2) & 185.5 & & & & \\
\hline & ST (3) & 152.7 & & & & \\
\hline & EST (1) & 203.3 & & & & \\
\hline \multirow[t]{3}{*}{10} & MT (2) & 173.3 & 2 & 9.7 & 0.0 & $1-2$ \\
\hline & ST (3) & 164.4 & & & & \\
\hline & EST (1) & 204.8 & & & & \\
\hline 11 & MT (2) & 183.9 & & 15.3 & 0.0 & $\begin{array}{l}1-3 \\
2-3\end{array}$ \\
\hline & ST (3) & 154.6 & 2 & & & \\
\hline & EST (1) & 175.1 & & & & \\
\hline 13 & MT (2) & 200.1 & 2 & 112.2 & 0.0 & $2-3$ \\
\hline & ST (3) & 158.6 & & & & \\
\hline & EST (1) & 146.5 & & & & \\
\hline 16 & MT (2) & 195.4 & 2 & 14.2 & 0.0 & $1-2$ \\
\hline & ST (3) & 179.5 & & & & \\
\hline & EST (1) & 200.8 & & & & \\
\hline 17 & MT (2) & 188.8 & 2 & 16.0 & 0.0 & $\begin{array}{l}1-3 \\
2-3\end{array}$ \\
\hline & ST (3) & 152.9 & & & & \\
\hline & EST (1) & 148.5 & & & & 0 \\
\hline 18 & MT (2) & 179.9 & 2 & 10.4 & 0.0 & $1-2$ \\
\hline & ST (3) & 191.3 & & & & \\
\hline & EST (1) & 197.9 & & & & \\
\hline 19 & MT (2) & 176.9 & 2 & 3.4 & 0.0 & $1-3$ \\
\hline & ST (3) & 164.6 & & & & \\
\hline & EST (1) & 148.9 & & & & \\
\hline 20 & MT (2) & 169.1 & 2 & 16.8 & 0.0 & $1-3$ \\
\hline & ST (3) & 200.1 & & & & \\
\hline & EST (1) & 152.7 & & & & \\
\hline 23 & MT (2) & 197.0 & & 10.5 & 0.0 & $1-2$ \\
\hline & ST (3) & 174.5 & 2 & & & \\
\hline & EST (1) & 203.6 & & & & \\
\hline 25 & MT (2) & 158.8 & 2 & 12.5 & 0.0 & $1-2$ \\
\hline & ST (3) & 176.4 & & & & \\
\hline & EST (1) & 221,8 & & & & $1-2$ \\
\hline 31 & MT (2) & 189.8 & 2 & 41.3 & 0.0 & $1-3$ \\
\hline & ST (3) & 139.6 & & & & $2-3$ \\
\hline & EST (1) & 208.0 & & & & \\
\hline 32 & MT (2) & 168.9 & 2 & 12.5 & 0.0 & $\begin{array}{l}1-2 \\
1-3\end{array}$ \\
\hline & ST (3) & 165.3 & & & & \\
\hline
\end{tabular}


When table 4 was analyzed, it was determined according to the Kruskal Wallis $\mathrm{H}$ results that the average scores of the teachers in Items 1, 6, 7, 8, 10, 11,13, 18, 19, 20,23, 25, 31 ve 32 show significant differences according to branch variable $(\mathrm{p}<0,05)$.

The Mann Whitney U-Test was used to determine the source of significant differences observed among the branches. Mathematics Teachers (MT) see themselves sufficient at a higher level than both Elementary school teachers (EST) and Science Teachers (ST) in the following areas.

- Being able to apply class activities for obtaining a product by integrating the information received in the fields of Science, Technology, Engineering and Mathematics (Item 1);

- Being able to guide students to convert scientific knowledge into a product or into practical knowledge (Item 6);

- Being able to make use of computer technologies such as interactive boards and tablet computers in classes (Item 11);

- Being able to combine experiments/activities in science or mathematics laboratory with engineering design processes (Item 17);

- Being able to make teaching intended for project-based learning approach (Item 20);

- Being able to guide students to produce research questions like scientists (Item 25);

- Being able to do include activities that will arouse the curiosity in students at every stage of classes while performing activities related to science, mathematics, technology and engineering (Item 32).

Mathematics Teachers see themselves sufficient at a higher level than Science Teachers in the following areas.

- Being able to use engineering applications in line with the levels of students (Item 13);

- Being able to teach intended for problem-based learning approach (Item 18);

- Being able to use process and result evaluation together (Item 23);

Mathematics Teachers and Science Teachers see themselves sufficient at a higher level than Elementary school teachers in the following areas.
- Being able to teach students to develop skills such as entrepreneurship and productive skills (Item 7);

- Being able to develop the measurement tools that measure the mental processes of students in activities such as investigation, research and invention (Item 10);

The other findings of the study are summarized as follows.

- Elementary school teachers consider themselves more sufficient than mathematics teachers; mathematics teachers consider themselves more sufficient than science teachers in terms of the acquisition of "Raising investigating and researching individuals (Item 8 )".

- Mathematics teachers and science teachers consider themselves more sufficient than elementary school teachers in terms of the acquisition of "Being able to associate instructional design (i.e. plan) with everyday life (Item 16)"

- Elementary school teachers consider themselves more sufficient than mathematics teachers and science teachers in terms of the acquisition of "Being able to teach intended for performance-based learning approach (Item 19)"

- Elementary school teachers and mathematics teachers consider themselves more sufficient than science teachers in terms of the acquisition of "Being able to include activities that will enable students to analyze, synthesize and evaluate information instead of memorizing (Item 31)"

The fact that mathematics and science teachers are more qualified than their elementary school teachers to have the skills required by STEM may be due to the fact that mathematics and science are more related to STEM education.

\section{The Findings on the differences between the readiness levels of the teachers on STEM Education according to Seniority Levels}

The results of the Kruskal Wallis Test analysis in which the teachers' readiness level for STEM education was examined according to the Seniority variable of the teachers are given in table 5 .

Table 5. The Kruskal Wallis H Results according to the seniority levels of the teachers on STEM Education

\begin{tabular}{|c|c|c|c|c|c|c|}
\hline Items & Seniority & Sum of squares & $\mathrm{df}$ & $\chi^{2}$ & $\mathrm{p}$ & Difference \\
\hline \multirow{5}{*}{16} & $0-5$ years $(1)$ & 198.9 & \multirow{5}{*}{4} & \multirow{5}{*}{10.2} & \multirow{5}{*}{0.0} & \multirow{5}{*}{$3-4$} \\
\hline & $6-10$ years $(2)$ & 169.8 & & & & \\
\hline & $11-15$ years $(3)$ & 195.8 & & & & \\
\hline & $16-30$ years $(4)$ & 157.3 & & & & \\
\hline & 31 years or more $(5)$ & 201.9 & & & & \\
\hline
\end{tabular}

Teachers with 11-15 years of seniority consider themselves more than teachers with 16-30 years of seniority in terms of the acquisition of "Associating teaching plan with everyday life (Item 16)". 


\section{Conclusions}

This study had the purpose of determining the readiness levels of the teachers working in Batman and Siirt in terms of STEM Education. The study was designed in the Review Model and the data were collected with the questionnaire that was prepared by the authors of the study.

According to the results of the study, teachers consider themselves sufficient in applying educational designs to educate producing and entrepreneur students who can solve real life problems with a disciplinary point of view.

Teachers consider themselves as sufficient at a moderate level in applying educational designs intended for develop products by integrating the science, technology, engineering and mathematics disciplines. Parallel to this result, Tutak, Akaygun and Tezsezen [20] reported that a few teacher candidates considered STEM education as "integrated teaching of the subjects" before they were trained on STEM. For example, they stated that they thought of STEM as associating natural sciences with mathematics only. However, STEM education requires that all disciplines should be studied in an integrated manner, not by associating a discipline with others.

They consider themselves sufficient at a moderate level in developing instructional designs that can transform scientific knowledge into practice and in training students to question knowledge, and in applying science-based, problem-based, project-based training in science-mathematics laboratory. In programs developed recently in Turkey [24, 25], it may be claimed that constructivist educational approach has been adopted. Teachers may have received knowledge through the use of these programs and through in-service trainings they received about these programs.

Teachers do not consider themselves sufficient in raising students who apply instructional designs that are inventive and that use scientific methods, who develop creative STEM products who evaluate the STEM products in a critical manner. In addition, they do not consider themselves sufficient in the areas of process evaluation, information technology-supported education, developing student-level engineering practices, and in including activities that involve analyses based on Bloom Taxonomy, and in activities that improve the skills at higher levels. It is considered as a usual situation for teachers because they have not received adequate knowledge in this field, and they have not been trained in any of the relevant disciplines of engineering and technology. These results show parallelism with the results reported in the study of Oner and Capraro [26]. They explained the lack of difference between the success levels of STEM schools and traditional schools with the quality of in-service training teachers received. They emphasized the necessity to raise teacher candidates in line with the integrated structure of STEM education. The results of the present study show that mathematics teachers are more sufficient in associating engineering subjects with other disciplines and in developing activities that students can use their scientific knowledge and scientific methods than elementary school teachers and science teachers. In addition, mathematics teachers consider themselves more sufficient than other branch teachers in problem-based learning, which is required for teaching STEM education, problem-based learning, information technology, and based on both course and result evaluation. A study that yielded similar results with science teachers belongs to [27]. According to this study, it was determined that science teacher candidates had difficulty in developing the most probable solutions in the middle and at the end of their evaluation the engineering design processes. Science and mathematics teachers consider themselves more adequate in the field of raising entrepreneur and productive individuals and in associating daily life with classes when compared with elementary school teachers. Elementary school teachers consider themselves more sufficient than science and mathematics teachers in questioning-based approach, performance-based approach, in realizing class applications appropriate to analysis of Bloom Taxonomy

Teachers with 11-15 years of seniority can associate the educational curriculum with everyday life and consider themselves sufficient at a higher level than teachers with 16-30 years of seniority.

In STEM education, teachers are required to be creative and integrate different disciplines and use the scientific method. According to the results of the present study, it is suggested to organize in-service trainings to the teachers on the subjects that they consider themselves inadequate. It is recommended that in-service training programs for STEM teachers are organized including the following acquisitions:

- Developing the learning-teaching activities that improve the invention skills of students,

- Guiding students to use scientific methods,

- Training students who can develop original STEM products,

- Developing measurement tools for process evaluation,

- Developing class designs supported with information technology,

- Designing activities that improve the skills at analysis level and at higher levels according to Bloom Taxonomy.

It is also recommended for researchers that qualitative studies are conducted about the educational needs of teachers in STEM Education in different cities, branches and school types, and on training STEM teachers. Studies investigating the effects of STEM training for teachers should be conducted. In these trainings, especially the applications of engineering and technology disciplines to be integrated with other disciplines should be included.. 


\section{REFERENCES}

[1] Sanders, M. (2009). STEM, STEM education, STEMmania. The Technology Teacher, 20-26. Retrieved from https://vtechworks.lib.vt.edu/bitstream/handle/10919/5161 6/STEMmania.pdf? sequence $=1$ \&isAllowed $=\mathrm{y}$

[2] Corlu, M. S. (2013). FeTeMM eğitimi makale çağr mektubu [Call for manuscripts on STEM education]. Turkish Journal of Education, 3 (1), 1-10. Retrieved from http://dergipark.gov.tr/turje/article/181071

[3] Ministry of Education (2016). Uluslararas1 fen ve Matematik Eğitimleri Araştırması [International Science and Mathematics Trends Research TIMSS 2015]. Ankara: Milli Eğitim Bakanlığı Ölçme Değerlendirme Genel Müdürlüğ̈̈.Retrieved from https://odsgm.meb.gov.tr/meb_iys_dosyalar/2017_06/2316 1945_timss_2015_on_raporu.pdf

[4] Wang, H. H., Moore, T. J., Roehrig, G. H. \& Park, M. S. (2011). STEM integration: Teacher perceptions and practice. Journal of Pre-Collage Engineering Education Research, 1 (2), 1-13. doi: 10.5703/1288284314636

[5] Bybee, R. W. (2010). What is STEM education. 326 (5995), 996 Science. doi:10.1126/science. 1194998.

[6] OECD, (2018), PISA 2015 Results in Focus. Retrieved from https://www.oecd.org/pisa/pisa-2015-results-in-focus.pdf

[7] Elmalı, Ş. \& Kıyıcı, F. B. (2017). Türkiye'de Yayınlanmış FeTeMM Eğitimi İle İlgili Çalışmaların İncelenmesi [Review of STEM Studies published in Turkey]. Journal of Sakarya Education, 7 (3), 684-696. doi: 10.19126/suje.322791

[8] Yamak, H., Bulut, N., \& Dundar, S. (2014). 5. sınıf öğrencilerinin bilimsel süreç becerileri ile fene karş1 tutumlarına FeTeMM etkinliklerinin etkisi [The impact of STEM activities on 5th grade students' scientific process skills and their attitudes towards science]. Journal of Gazi University Faculty of Education, 34 (2), 249-265. doi: 10.17152/gefd. 15192

[9] Marulcu, İ. \& Sungur, K. (2012). Fen bilgisi öğretmen adaylarının mühendis ve mühendislik algılarının ve yöntem olarak mühendislik-dizayna bakış açılarının incelenmesi [Investigating pre-service science teachers' perspectives on engineers, engineering and engineering design as context]. Afyon Kocatepe University Journal of Science, 12 (1), 13-23. Retrieved from http://dergipark.gov.tr/akufemubid/issue/1593/19804

[10] Sonmez, V. (2003). Program Geliștirme Öğretmen El Kitab1 [Teacher handbook to develop the program]. Ankara: Pagem.

[11] Corlu, M. S., Capraro, R. M. \& Capraro, M. M. (2014). Introducing STEM education: Implications for educating our teachers for the age of innovation. Education and Science, 39 (171), 74-85. Retrieved from http://dspace.bilkent.edu.tr/bitstream/handle/11693/13203/ 7283.pdf? sequence $=1 \&$ is Allowed $=y$

[12] Ercan, S. (2014). The usage of engineering practices in science education: Effects of design based science learning on students' academic achievement. Necatibey Faculty of Education Electronic Journal of Science and Mathematics Education, 9,(1), 128-164. doi: 10.19126/suje.322791
[13] Eroglu, S. \& Bektas, O. (2016). Ideas of Science Teachers took STEM education about STEM based activities Journal of Qualitative Research in Education, 4 (3), 43-67. doi :10.14689/issn.2148-2624.1.4c3s3m

[14] Yıldırım, B., \& Altun, Y. (2015). STEM eğitim ve mühendislik uygulamalarının fen bilgisi laboratuar dersindeki etkilerinin incelenmesi [Investigation of the effects of STEM education and engineering applications in the science laboratory course]. El-Cezeri Journal of Science and Engineering, 2(2), 28-40 Retrieved from https://www.researchgate.net/profile/Bekir_Yildirim2/publ ication/277797005_STEM_Egitim_ve_Muhendislik_Uygu lamalarinin Fen Bilgisi Laboratuar Dersindeki Etkilerini n_Incelenmesi/links/5573f4e408aeacff1 ffca638.

[15] Han, S., Yalvac, B., Capraro, M. M. \& Capraro, M.R. (2015). In-service teachers' implementation of and understanding from project-based learning (PBL) in science, technology, engineering, and mathematics (STEM) project-based learning, Eurasia Journal of Mathematics, Science ve Technology Education, 11 (1), 63-76. doi: 10.19128/turje.181071

[16] Higher Education Board (2007). Eğitim Fakültesi öğretmen yetiştirme programları [Faculty of Education Teacher Training Undergraduate Programs]. Ankara: Yüksek Öğretim Kurulu Başkanlığı Retrieved from http://www.yok.gov.tr/documents/10279/30217/E\%C4\%9 E\%C4\%B0T\%C4\%B0M+FAK\%C3\%9CLTES\%C4\%B0 $\% 20 \% \mathrm{C} 3 \% 96 \% \mathrm{C} 4 \% 9 \mathrm{ERETMEN}+\mathrm{YET} \% \mathrm{C} 4 \% \mathrm{~B} 0 \% \mathrm{C} 5 \% 9$ ET\%C4\%B0RME+L\%C4\%B0SANS+PROGRAMLARI.p df/054dfc9e-a753-42e6-a8ad-674180d6e382

[17] Karasar N. (2016). Bilimsel Araştırma Yöntemi [Scientific research method]. Ankara: An1 Publishing.

[18] Buyruk, B., \& Korkmaz, Ö. (2014). FeTeMM farkındalık ölçeği (FFÖ): geçerlik ve güvenirlik çalışması [STEM Awareness Scale (SAS): Validity and Reliability Study] Journal of Turkish Science Education, 11(1), 3-23. doi: 10.12973/tused.10179a

[19] Derin, G., Aydın, E., \& Kırkıç, K. A. STEM (Fen-Teknoloji-Mühendislik-Matematik) Eğitimi Tutum Ölçeği [A Scale on the Attitudes towards STEM Education]. El-Cezeri Journal of Science and Engineering, 4(3), 547-559. Retrieved from https://s3.amazonaws.com/acade mia.edu.documents/54718331/STEM_Tutum_-_Cezeri.pdf ?AWSAccessKeyId=AKIAIWOWYY GZ2Y $\overline{53} \overline{\mathrm{UL}} 3 \mathrm{~A} \& \mathrm{Ex}$ pires $=1532591611 \&$ Signature $=$ C1t 1 zNSStPs719k4LIOIiv px44Q\%3D\&response-content-disposition=inline $\% 3 \mathrm{~B} \% 20$ filename\%3DSTEM_Egitimi_Tutum_Olcegi.pdf

[20] Tutak, A. F., Akaygun, S. \& Tezsezen, S. (2017). FeTeMM (Fen, Teknoloji, Mühendislik, Matematik) eğitimi uygulaması: kimya ve matematik öğretmen adaylarının FeTeMM farkındalıklarının incelenmesi. [Collaboratively learning to teach STEM: Change in participating pre-service teachers' awareness of STEM]. Journal of Hacettepe University Faculty of Education, 32 (4), 794-816. doi: 10.16986/HUJE.2017027115

[21] Kizılay, E. (2017). The adaptation of STEM semantics survey into Turkish. The Journal of Academic Social Science Studies. 58,131-144, doi:10.9761/JASSS7144.

[22] Haciomeroglu, G., \& Bulut, A. S. (2016). Entegre FETEMM öğretimi yönelim ölçeği Türkçe formunun geçerlik ve güvenirlik çalıșması [Integrative STEM 
teaching intention questionnaire: a validity and relaibility study of the Turkish Form]. Ë̌itimde Kuram ve Uygulama, 12(3), 654-669. Retrieved from http://dergipark.gov.tr/dow nload/article-file/262361

[23] Cevik, M. (2017). A study of STEM Awareness Scale development for high school teachers. International Journal of Human Sciences, 14 (3), 2436-2452. Retrieved fromhttps://www.j-humansciences.com/ojs/index.php/IJHS /article/view/4673/2265

[24] Ministry of Education (2004). İlköğretim fen ve teknoloji programı [Primary science and technology program]. Ankara: Milli Eğitim Bakanlığı.

[25] Ministry of Education (2016), İlköğretim fen ve teknoloji

\footnotetext{
${ }^{\mathrm{i}}$ This article is an improved version of a paper presented orally in 1st International Teacher Education and Accreditation Congress, 19-21 May 2017, Istanbul/Turkey.
}

program1 [Primary science and technology program]. Ankara: Milli Eğitim Bakanlığı

[26] Oner, A. T., \& Capraro, R. M. (2016). Is STEM Academy Designation Synonymous with Higher Student Achievement? Education and Science, 41 (185), 1-17. doi:10.1155/2012/490647

[27] Altan, E. B., Yamak, H., \& Kırıklaya, E. B. A. (2016). Hizmetöncesi öğretmen eğitiminde FETEMM eğitimi Uygulamaları: Tasarım temelli fen eğitimi [Proposal of the STEM Education for Teacher Training: Design Based Science Education]. Journal of Trakya University Faculty of Education. 6 (2), 212-232. Retrieved from http://dergipark.gov.tr/download/article-file/222656 